\section{Broadening Participation in the Sciences within and from Africa: Purpose, Challenges, and Prospects}

\author{
Iruka N. Okeke, ${ }^{+*}$ Chinedum P. Babalola, ${ }^{\dagger}$ Denis K. Byarugaba, ${ }^{*}$ \\ Abdoulaye Djimde, $\S$ and Omolaja R. Osoniyi" \\ ${ }^{\dagger}$ Faculty of Pharmacy, University of Ibadan, Ibadan, Nigeria; 'Department of Microbiology, \\ Makerere University, Kampala 7062, Uganda; \$Malaria Research and Training Center, Department \\ of Epidemiology of Parasitic Diseases, Faculty of Pharmacy, University of Science, Techniques \\ and Technologies of Bamako, Bamako, Mali; "Department of Biochemistry, Obafemi Awolowo \\ University, Ile-Ife, Nigeria
}

\begin{abstract}
Many of Africa's challenges have scientific solutions, but there are fewer individuals engaged in scientific activity per capita on this continent than on any other. Only a handful of African scientists use their skills to capacity or are leaders in their disciplines. Underrepresentation of Africans in scientific practice, discourse, and decision making reduces the richness of intellectual contributions toward hard problems worldwide. This essay outlines challenges faced by teacher-scholars from sub-Saharan Africa as we build scientific expertise. Access to tertiary-level science is difficult and uneven across Africa, and the quality of training available varies from top-range to inadequate. Access to science higher education needs to increase, particularly for female students, first-generation literates, and rural populations. We make suggestions for collaborative initiatives involving stakeholders outside Africa and/or outside academia that could extend educational opportunities available to African students and increase the chance that Africa-based expertise is globally available.
\end{abstract}

\section{INTRODUCTION}

African nationals are underrepresented in global science, and within African countries, access to science education is often difficult and uneven. Domestic scientific and engineering expertise does not meet the African continent's needs, and most scientific and technological materials and services are imported. These facts have profound implications for development. Overall, the underrepresentation of scientists in low-income countries, particularly those in Africa (Table 1), is a principal contributor to the "10/90 gap," in which only an estimated $10 \%$ of the funding for global health research is used to address the health problems of $90 \%$ of the world's poorest people (Ramsay, 2001), and analogous gaps in other technology-dependent sectors, including agriculture, industry, and information technology. While the data presented in Table 1 represent improvements on earlier years, these gaps cannot be closed without significantly growing, diversifying, and retaining the scientific workforce from the most affected countries. Africa faces the dual challenge of locally recruiting and retaining diverse talent and ensuring that trainee scientists receive the necessary science, technology, engineering, and mathematics (STEM) skills and resources to effectively compete and interact with their peers worldwide.

In this Essay, we present recommendations for increasing access and improving the quality of participation of Africans in the sciences. African science suffers from limited diversity in the academy, and global participation is inhibited by the shortage of leading scientists. These problems and those that they impact, outlined in the previous paragraph, are of global concern, because the science knowledge-space is global, and therefore exclusions within and from the African continent impact knowledge more
Pat Marsteller, Monitoring Editor Submitted December 30, 2015; Revised December 29, 2016; Accepted January 6, 2017

CBE Life Sci Educ June 1, 2017 16:es2 DOI:10.1187/cbe.15-12-0265

*Address correspondence to: Iruka N. Okeke (iruka.n.okeke@gmail.com).

(c) 2017 I. N. Okeke et al. CBE-Life Sciences Education ๑ 2017 The American Society for Cell Biology. This article is distributed by The American Society for Cell Biology under license from the author(s). It is available to the public under an Attribution-Noncommercial-Share Alike 3.0 Unported Creative Commons License (http://creativecommons.org/licenses/ by-nc-sa/3.0).

"ASCB®" and "The American Society for Cell Biology $® "$ are registered trademarks of The American Society for Cell Biology. 
TABLE 1. Sub-Saharan Africa's contributions to the global scientific enterprise (2013-2014)

\begin{tabular}{lc}
\hline Indicator & $\begin{array}{c}\text { Proportion on } \\
\text { the African } \\
\text { continent }\end{array}$ \\
\hline Global population & $12.5 \%$ \\
Contribution to global gross domestic product (GDP) & $3.0 \%$ \\
Gross expenditure on research and development as & $0.7 \%$ \\
$\quad$ percentage of GDP & $1.1 \%$ \\
World's scientific researchers & $0.1 \%$ \\
Global patents filed & $1.4 \%$ \\
Scientific papers published in 2014 &
\end{tabular}

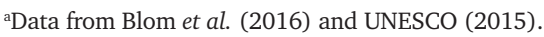

generally. Additionally, African institutions can learn from and teach about global inequitable access to science of economic, gender and sexuality, and ethnic minorities. Broadening participation will increase access for the underrepresented along with increasing access overall.

It is important to emphasize that, when the opportunity to engage in science is extended to previously underrepresented groups, groups other than those targeted benefit as well. A recent paper documenting the remarkable rapidity with which gender equity among the speakers at the American Society for Microbiology (ASM) was achieved highlighted the contribution that equity will make to career development and advancement for current and future female microbiologists (Casadevall, 2015). What the piece did not mention, however, is whether male as well as female participants benefited from the greater diversity of observations and opinions. In the same vein, international programs that could develop scientific capacity in Africa are almost always presented in a framework that highlights the many benefits these programs will offer to lower-income African countries. However, while simultaneously offering benefits for Africa and its scientists, African participation in global scientific endeavors advances fields globally as well as the careers of non-African scientists (Crane, 2013; Geissler and Okwaro, 2014; Moyi Okwaro and Geissler, 2015; Blom et al., 2016). Similarly, African science will benefit from increased participation from locally underrepresented groups-women, first-generation literates, and individuals residing in rural areas who represent the gendered, generational, and geographical minorities we highlight in this article.

We acknowledge that there are very limited published data from sub-Saharan Africa on inclusion and participation in the sciences. We have therefore augmented interpretations of the available data with our own experiences to buttress the need for broadening the participation of Africa in science. This essay largely focuses on Africa south of the Sahara, where conditions are generally different from most North African countries. However, there are many between- and within-country differences. We have endeavored to draw general conclusions when data are available from four or more countries in different regions of Africa, with the knowledge of the limitations of the data available, and we have attempted to fill the gaps with qualitative observations to produce a more generalized picture.

\section{UNDERREPRESENTATION IN AFRICAN SCIENCE: GEOGRAPHY, GENDER, AND GENERATION Geography: Rural Participation}

African institutions of higher learning draw most of their students from cities, particularly those that were colonial entry points (Manuh et al., 2007). The University of Dar es Salaam recruits almost half of its students from only two regions in Tanzania (Cooksey et al., 2003), and in Mozambique, areas proximal to Maputo accounted for $60 \%$ of university enrollments but only $26 \%$ of the population in 2000 (Mário et al., 2003). Similarly, one biomedical research study that recruited participants from a pre-pharmacy college freshman class in southwest Nigeria found that $37 \%$ came from families residing in the urban metropolis Lagos (Lamikanra and Okeke, 1997), even though there were five universities within or closer to Lagos than the study campus at that time. Only six of the 75 students were from nonurban areas.

The predominance of urban students on African campuses has important class implications. In Ghana, 50 elite schools (representing less than $9 \%$ of senior secondary schools nationally) contributed $75 \%$ of university enrollments in 2000 (Manuh et al., 2007). Elite secondary school graduates easily outcompete the relatively fewer rural candidates at highly competitive university entrance examinations. In most cases, university lecturers have largely studied in the same elite schools. Such a situation (analogous to the British public schools "old boys' clubs") represents a less diverse set of each nation's talent. The minority of students from nonelite secondary schools who successfully scale the high bars to admission despite inadequate preparation often represent their country's most promising talent. Their different backgrounds and connections make them a potential pool of innovative ideas that are different from the more "Westernized" elite. They are, however, at higher risk of dropping out of university due to tuition or family and community pressure to earn money immediately after secondary education. Africa's elite girls' schools such as Queen's College (Nigeria), Mariama Bâ de Gorée School (Senegal), or Wesley Girl's High School (Ghana) have exemplary records of drawing young women into STEM careers, effectively addressing our next focal broadening participation challenge. One way to strike a balance between the advantages provided by elite schools and reduced access for provincial students is to improve access to boarding schools for rural secondary school candidates.

\section{Gender: Women}

While underrepresentation of women is not the only gender underrepresentation issue to consider, this long-standing problem is the focus of gender inequality and parity discussions in most African countries. In Mozambique, the ratios of males to females at primary, secondary, and university levels were, respectively, 1.3:1, 1.4:1, and 2.5:1 in 1997 (Mário et al., 2003). ${ }^{1}$ Addressing such inequities is a priority in the recently concluded Second Decade of Education for Africa Plan of Action (African Union [AU], 2006), and the goal to eliminate gender

\footnotetext{
${ }^{1}$ Primary school male to female ratios reached $1.2: 1$ in 2008 and, at that time, were predicted to reach parity in 2015. Ratios at higher education levels, particularly in rural areas, will trail primary ones for at least some years to come (Multiple Indicator Cluster Survey data 2008 retrieved from http://data.unicef.org).
} 


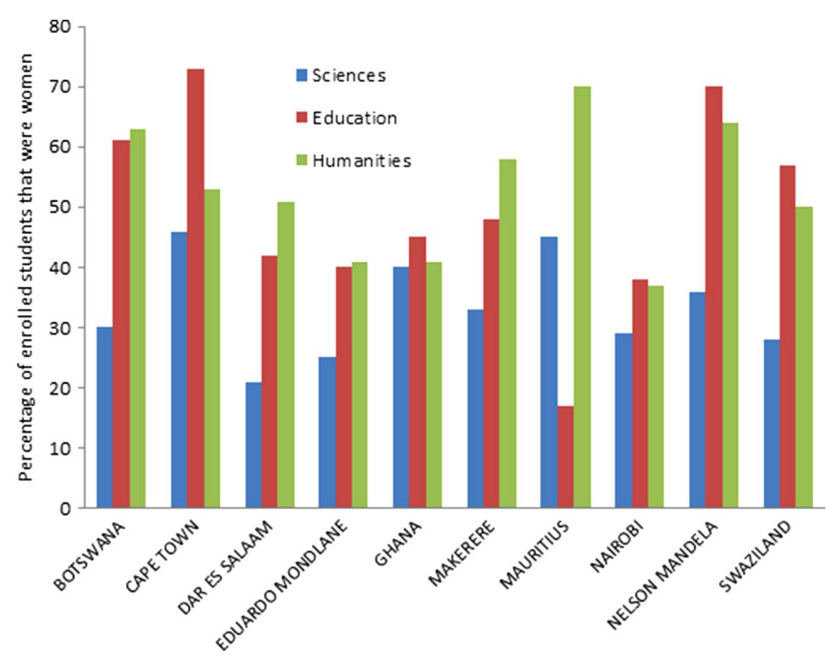

FIGURE 1. Percentage of 2009-2010 enrollees in the sciences, education, and humanities at 10 flagship universities in African countries who were women. Data from Bunting et al. (2014) and ASSAf (2012).

disparities includes a focal point to enhance female engagement with and participation in science and technology (AU, 2006). Nonetheless, women continue to be less likely to enroll in university science courses than men. Figure 1 shows the proportion of female students enrolled in core science courses at 10 flagship African universities in the 2009-2010 academic year compared with education and humanities programs. With few exceptions, female enrollments were lower in the sciences. Importantly, the studies from which these data were obtained show gradual increases in non-science female enrollments over a 3-year period. However, with the exception of Dar es Salaam, Mauritius, and Nelson Mandela universities, female enrollments in the sciences did not change, or dropped.

STEM female graduation trends are even more worrisome. The proportion of Swaziland female diploma, baccalaureate, and master's graduates in the natural sciences fell from $47.2 \%$ to $42.3 \%$ between 2000 and 2008. In engineering and technology, only $7.7 \%$ of 2008 graduates were female, down from $12.5 \%$ in 2000 (Academy of Science of South Africa [ASSAf], 2012). During the reporting period, the percentage of female graduates rose in other areas, exceeding $50 \%$ of the total for the health sciences, humanities, commerce, and education. Eight other flagship institutions also record greater female graduation rates outside the sciences in that same period (Bunting et al., 2014).

In the Swaziland study, distance-learning programs recorded a 59\% female enrollment (ASSAf, 2012): it is not uncommon to see higher female enrollments in nonresident programs than residential ones. As science programs are predominantly residential, female students who cannot undertake residential programs due to domestic commitments may be excluded from science. However, other factors contribute to the differences in enrollment and graduation seen in the sciences compared with other disciplines. Available data suggest that overt discrimination against and discouragement of female science students is one of those factors (Manuh et al., 2007; ASSAf, 2012).
Male to female imbalances become even more pronounced at the postdoctoral and junior faculty levels. As new female graduates begin families, social pressure and household commitments discourage or hamper their progress in science. Indeed, in the field of malaria research, where there is a critical mass of Africa-based experts, the number of female research leaders in Africa is currently in the single-digit range. The problem of female underrepresentation is compounded by the fact that, in many African societies, women shoulder most of the responsibility for work in the home (Okeke-Ihejirika, 2004; Adichie, 2012; Pearson, 2015). The availability and cost of employing domestic assistance has risen since independence to beyond what many professional young women, including scientists, can afford, while traditional community-based childcare support is limited or not available in cities and university towns. These domestic pressures on female scientists are rarely documented, and systematic information on the effects of responsibilities outside the workplace is difficult to come by, even though it may be a significant factor depleting the pipeline of female scientists and mentors. As elsewhere in the world, childcare is a key need for women considering careers in science and constrains women scientists in Africa (Martinez et al., 2007). Difficulties with childcare provision may also prevent men who do contribute to childcare and homebuilding from engaging in science, even though they might be more supportive of women in science.

\section{Generational: First-Generation Literates}

The children of schooled parents are also more likely themselves to complete basic education. In Mozambique, $78.8 \%$ of men and $89.3 \%$ of women had no formal education in 1997 , while only $8 \%$ of the fathers and $2 \%$ of the mothers of university students had never been to school (Mário et al., 2003). Thus, the rarely remarked-upon underrepresentation of first-generation literates, that is students whose parents cannot read and write, is perhaps the greatest disparity between the ivory tower and the rest of Africa's society. Overall, the school-educated earn more and can therefore afford the fees and associated costs of their children's education as well as the cost of supporting them until they reach adulthood. Educated parents also recognize that higher education can keep their children in or above the middle class.

First-generation literates are more likely to have an African mother tongue or to be familiar with indigenous arts, crafts, and sciences, so that their exclusion from the academy in general and the sciences in particular locks out important non-Western knowledge and modes of thought. Intriguingly, a Mozambique study found that children of mothers with no postsecondary education who did matriculate were more commonly enrolled in the natural sciences and education than other disciplines, including medicine, social sciences, and the arts (Mário et al., 2003).

\section{Access Is Growing, but Representation Is Not}

The United Nations Educational Scientific and Cultural Organization (UNESCO) and the World Bank estimate gross underrepresentation in science from African countries (Table 1), and while there has been positive change in the current millennium, documentary evidence illustrates that these gains are a slow rebound from a steep decline in African contributions to science 
(a)

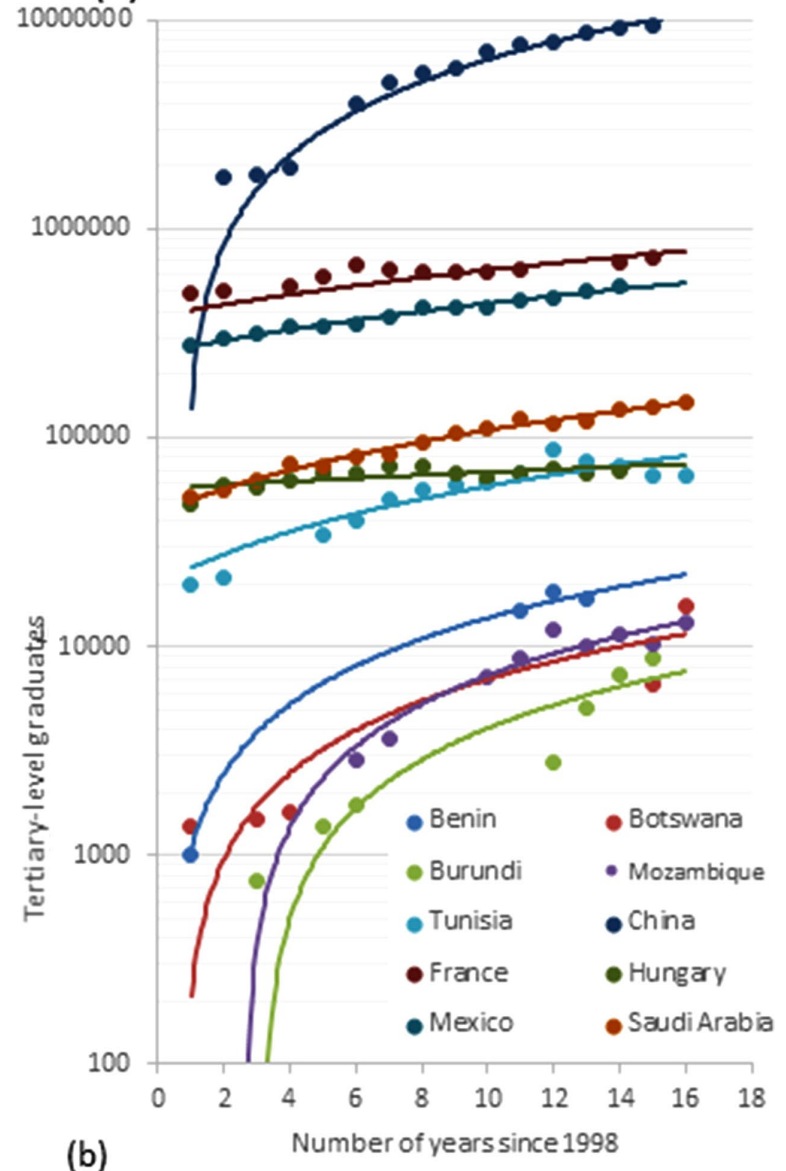

(b)

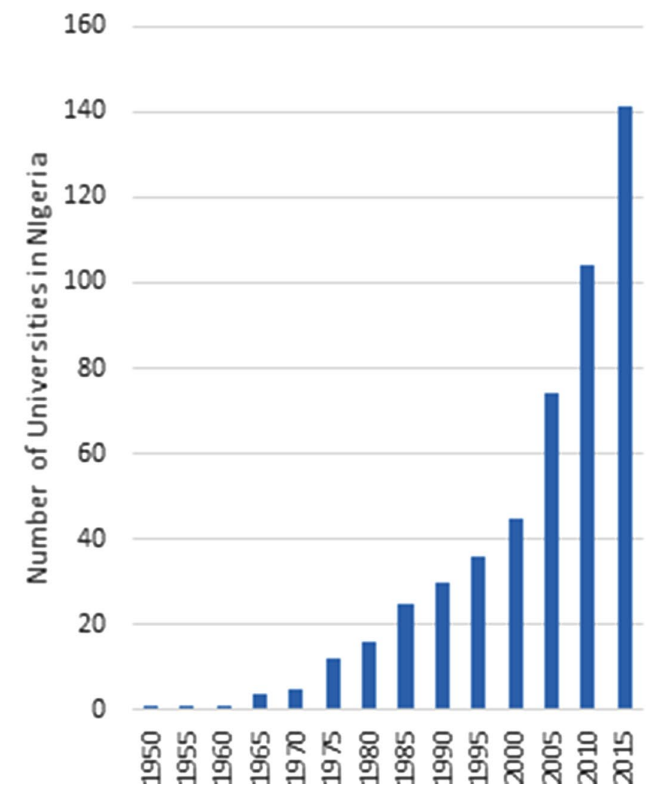

FIGURE 2. (a) Trend lines in the number of tertiary-level graduates from Benin, Botswana, Burundi, Mozambique, and Tunisia between 1999 and 2014 compared with graduates from countries in other world regions. The plots were generated using data from the UNESCO Institute for Statistics (http://data.uis.unesco.org). (b) The number of universities in Nigeria has increased from one in 1948 to 141 in 2015 (Nigerian Academy for Science). over the past four decades (Mouton, 2008). This decline, and the large youth population on the continent, necessitates a massive increase in human and institutional resources. In response, access to college and postgraduate education is expanding across the continent, and Africa's universities are among the newest and fastest-growing in the world. Figure 2a illustrates that, while African countries generally produce fewer graduates than other countries, the rate of increase since the 1990s has been much greater in Africa than elsewhere, with the possible exceptions of India and China. In Nigeria, successive governments have sought to broaden access by establishing more universities (Figure 2b; Anyanwu, 2011). Growth in the number and variety of higher institutions in many other countries has been similarly rapid, but university places are still too limited. Resource-intensive courses in the experimental sciences may have been particularly underserved by rapid expansion that has outpaced resource availability.

Special difficulties associated with acquiring a college education in African countries (such as lack of resources or credit toward meeting the financial demands of college and the expectation that students who leave school will support the education of younger siblings by immediately entering employment or marriage) make the prospect of doing so less attractive or less possible for underrepresented groups. Long durations of undergraduate training due to high failure rates (as in Mozambique; Mário et al., 2003) or repeated system strikes (as in Nigeria) mean that candidates who cannot afford six or more years of higher education in early adulthood are discouraged from seeking or completing a degree. These individuals include those in the lowest income brackets and women in societies that encourage, or even require, early marriage and reproduction. Nontraditional college-based programs could increase access for students who cannot spend 4-6 years in residence. While open and distance-learning programs may be difficult to implement in the laboratory sciences, evening and sandwich courses ${ }^{2}$ have real potential to maximize the use of existing infrastructure, provided that staffing and occupancy issues associated with integrating them with residential programs can be worked out.

Highly selective institutions are predominantly populated by students who have elite preparation. This presents a challenge for recruiting disadvantaged underrepresented groups. In the past two decades, new African private universities have increased the number of available university places and their geographic spread, broadening access to individuals who cannot attend older public institutions. Private universities also bring competition into the higher education sector, which could motivate public university reforms and improve efficiency and equitable access and representation by underrepresented groups. However, they raise important questions about quality. The number of qualified faculty in most African countries has remained static or declined due to brain drain (Kaba, 2004, 2011; Bassioni et al., 2016). Thus, many private institutions are staffed by underqualified lecturers or by part-time staff who hold positions at other institutions.

\footnotetext{
${ }^{2}$ Sandwich courses are scheduled around the schedules of working students. They typically take longer to complete, have shorter on-campus requirements, and are administered as distance-learning courses.
} 


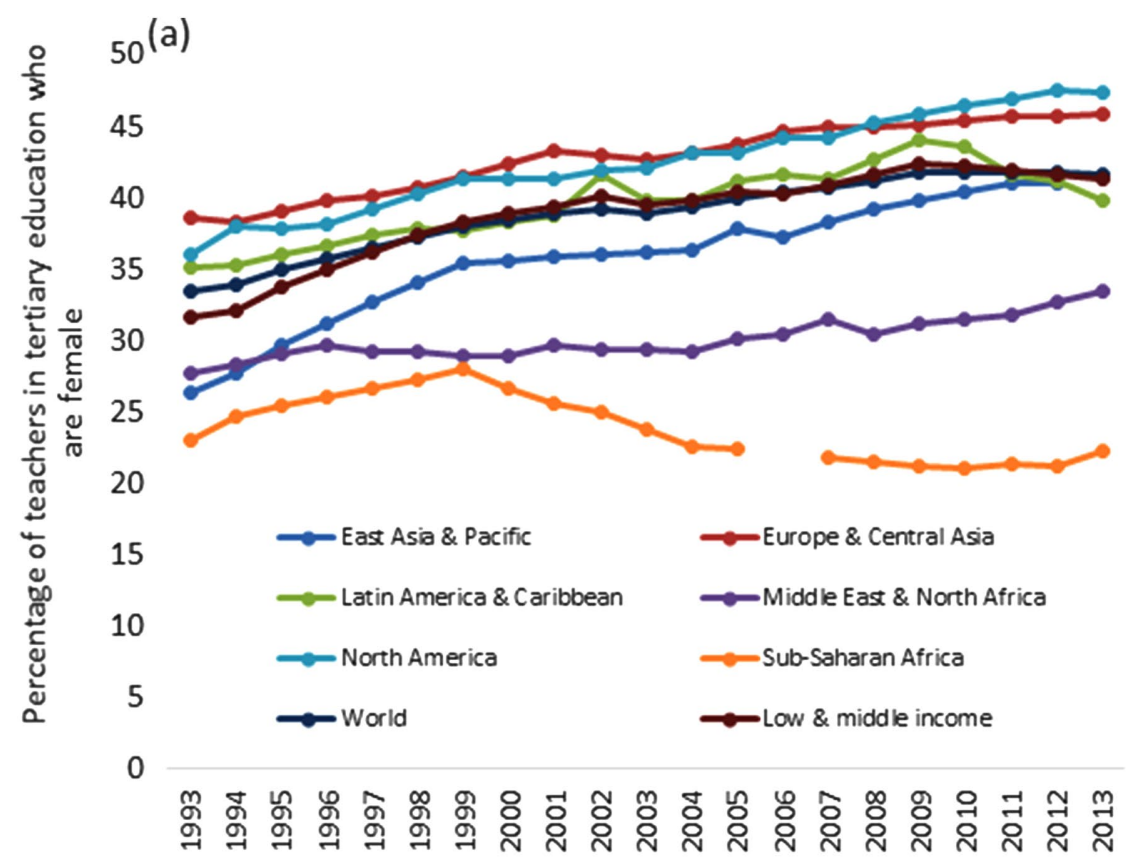

(b)

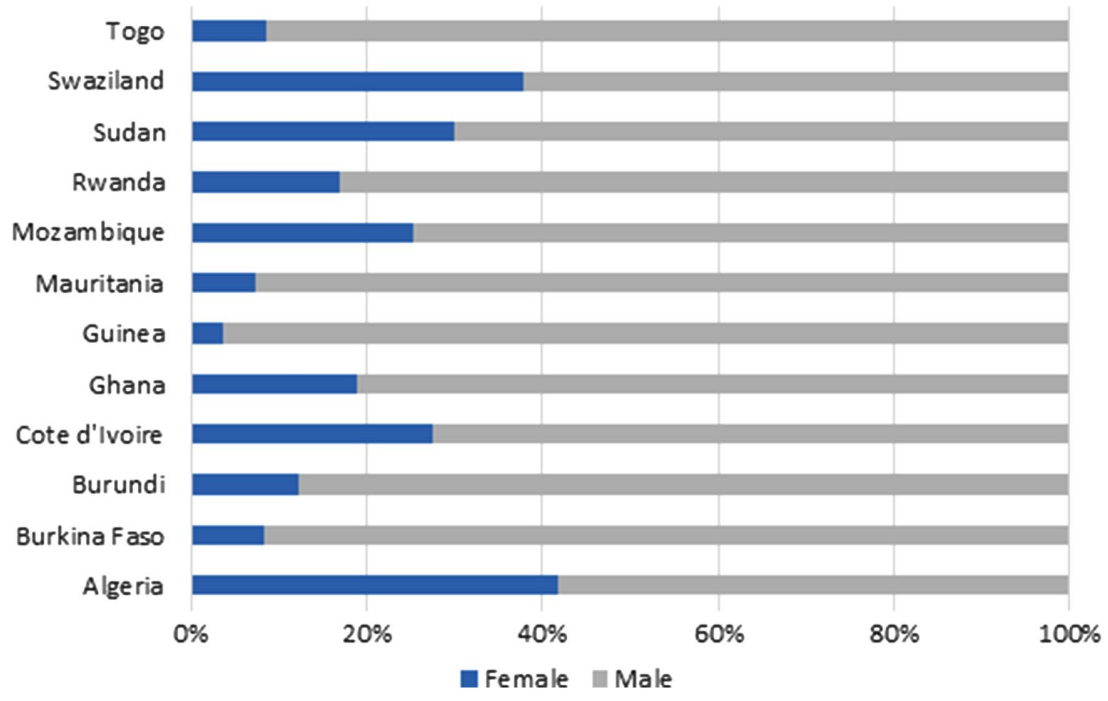

FIGURE 3. (a) Trends in the percentage of tertiary-level educators who are female worldwide, in low-income countries, and in different world regions, including sub-Saharan Africa, between 1993 and 2013. (b) Percentage of tertiary-level educators who were female in 2013 in 12 African countries. Data retrieved from http://data .worldbank.org/data-catalogue/world-development-indicators.

They are often insufficiently backed by endowments or state support. Exclusive support from fees makes resource-intensive experimental science courses impossible to deliver (Mário et al., 2003; Manuh et al., 2007). For all of these reasons, few private universities have significant enrollments in the sciences. Many of the better-endowed private universities are religious ones in which the teaching of certain subjects, for example, evolutionary biology, may be restricted or curtailed.

\section{IMPROVING GENDER REPRESENTATION}

The United States, which graduates severalfold more scientists than all African countries combined, is unable to meet its human resource needs in STEM. Experts have identified inadequate preparation for college-level STEM courses (particularly in mathematics), lackluster introductory courses, and a culture in science that many students, particularly those from underrepresented groups, perceive as unwelcoming as major factors hampering broadened participation (Gates and Mirkin, 2012). While many of the specific issues leading to these deficits are different from those in African countries, the hurdles that must be overcome are remarkably similar. Underrepresentation of women in African science has received the most attention. There are now evidence-based methods to achieve gender parity, and there is much that countries in Africa and elsewhere can learn from one another in dealing with this problem.

It is important to acknowledge that underrepresentation of women in science cannot be addressed at lower levels alone in the hope that advantaged girls will "grow through the system." The low proportion of women in science is due to low initial enrollments, failures in retention, and paucity of mentors and role models at higher levels, which reduces the motivation for aspiring female scientists. All of these are in turn fueled by societies and academies that are less welcoming and accommodating of girls and women than they are of boys and men. One strategy with documented success in U.S. universities provides mentored research opportunities for students from underrepresented groups. Students who participate in mentored research are more likely to stay in science (Hippel et al., 1998; Gregg-Jolly et al., 2011). Providing this type of opportunity for groups underrepresented in other parts of the world, including our own, will depend in no small part on mentor availability as well as resources for research. Although mentors of women scientists do not have to be female, female mentors can serve as important role models. Female role modeling is not only directed at young women, it demonstrates to societies, institutions, and individuals that broadening participation of the underrepresented gender improves the quality, extent, and reach of science.

There are considerable variations in female participation in science among countries. Of those for which data were available in 2013, the range is between 8\% (Togo and Burkina Faso) and 47\% (Algeria, in North Africa; Figure 3b). At 47\%, Tunisia 
(in North Africa) is the only country on the African continent that has a scientific research workforce in which women are almost equally represented ( $\geq 45 \%$ of researchers are women). No country in sub-Saharan Africa has achieved gender equity in the sciences, including in basic research, despite deliberate efforts in this direction; for example, no West African country has reached the $25 \%$ mark for women researchers in the sciences.

The Swaziland Women in Science survey found that most women who pursued careers in science and technology made the decision to do so in or before their teens and were motivated by secondary school teachers (ASSAf, 2012). More African women pursue nursing than other STEM careers, and female role models are plentiful and visible in nursing. The Swazi survey data demonstrate that life scientists earn more and have more satisfaction and a better work-life balance than nurses (ASSAf, 2012). This suggests that early and increased exposure to successful female scientists may motivate more women to pursue sciences. A nonprofit organization, African Research Academies for Women (www.africanwomenresearchers .org) proposes to address the need for academic support and role models through funded research studentships for undergraduates. Competitive summer research studentships are awarded to promising female students, who work with preselected successful female, or if necessary male, mentors and develop a mentoring relationship that endures beyond the research experience. The program is currently being piloted in Ghana and offered five studentships in 2014.

Swazi women have cited insufficient access to scholarships, study funds, and conference support as a limitation to their career development (ASSAf, 2012). Such support is particularly valuable in societies where family support is preferentially assigned to educating boys and men. The Makerere University Female Scholarship Foundation is one example of a program with the goal of improving the enrollment, retention, and performance of female undergraduates with specific emphasis on the sciences. The program, which gives priority to applicants from disadvantaged backgrounds and underrepresented geographical areas within Uganda, has seen an increase in the number of women participating in science. This, and additional interventions to promote women's success on campus, increased the number of female students participating in science (http:// mak.ac.ug/makerere-university-female-scholarship-foundation). Mozambique has also used targeted scholarships to increase university enrollment of women and of students from areas outside of Maputo (Mário et al., 2003). In a country where fewer than $3 \%$ of those entering primary school can be assured of a university place, Ghana's University of Development Studies (UDS) implemented a radical affirmative action program, accepting all female applicants who met the basic admission criteria in 2002. This lowered the undergraduate male to female ratio from 3:1 to 2.2:1 in a single year (Manuh et al., 2007). UDS similarly decided to sort students meeting basic entry requirements by secondary school, thereby devising a scheme to identify and admit the top students from underrepresented school clusters and improve geographical representation (Manuh et al., 2007).

African societies traditionally had structures that allowed women to weigh in significantly in decision making, but many of these were dismantled during colonialism (Okeke-Ihejirika,
2004; Awe, 2005). At leadership levels, there are too few African women in science and technology, and they face unique challenges that curtail their contributions to society. Nobel laureate Wangari Maathai, herself a science leader and the first woman from Kenya to obtain a $\mathrm{PhD}$ in biology, has been quoted as remarking that there are fewer women "the higher you go" (Adichie, 2012). Only four of the University of Ghana's 56 full professors were female in 2004 (Manuh et al., 2007). And at the start of 2015, the World Academy of Sciences (formerly the Third World Academy of Sciences), whose purpose is the advancement of science in developing countries, including those in Africa, had 1148 fellows, of whom 10\% were female (Chunii, 2015); similar proportions were seen in African academies. For example, as of 2015, only 37 (12\%) of 330 fellows of the African Academy of Sciences were female. Between 1980 and 1997, the Nigerian Academy did not elect any female fellows, and there were only 14 (6.9\%) as of 2015.

National academies determine local science policies, make selections for prestigious scientific prizes, feature in public venues nationally, and are often the international face of domestic science. Women are underrepresented in these critical decision-making and exposition venues. Existing female fellows expend relatively more time serving in these capacities in the efforts to seek representation within predominantly male academies. When females in positions of academic leadership are not only underrepresented but rare, there are real risks of stereotype threat and tokenism, which could be harmful to their own careers and those of others (Niemann, 2012). Thus, increasing the proportion of female electees is critical for correcting the science gender biases in other venues and assuring continued prominence of female leaders in science in their fields.

A UNESCO workshop for university women decision makers and midcareer women scientists and engineers emphasized that, to achieve the necessary socioeconomic transformation in Africa, female scientists must be placed center stage (www .unesco.org/new/en/natural-sciences/science-technology/ sti-policy/africa/promoting-women-in-science-in-africa). The meeting fell short of proposing a concrete implementation strategy. Even more worrying is that, even though we identify gender imbalances at all levels, these disparities in at least some African universities may be viewed as an opportunity for attracting resources rather than a problem to be addressed. Ambitious and competent women in academia-students and faculty alike-are branded as arrogant or aggressive (Manuh et al., 2007). The examples presented here notwithstanding, too little is occurring beyond discourse and initiatives to support African women in science; we need to progress more forcefully to actions (Olabisi, 2014). Current initiatives place emphasis on much-needed education of girls and young women. However, in addition to filling the pipeline, the continent is in great need of women's ideas, skills, and capabilities to help shape high-level policies; therefore, interventions must be made at both higher and entry levels now. As introduced in the section Gender: Women, many of the factors limiting women's attraction to and participation in the sciences are structural. Postcolonial African girls generally express a desire for education, and when they do not, it is more commonly because others make this goal difficult or impossible (Cornwall, 2005). Analogously, it is probable that societal and institutional changes that make science departments and programs more 
welcoming to women will have the most impact. As they battle resource limitations and other problems, African university administrations often pay little more than lip service to diversity issues. An important beginning will be for academic leaders to make inclusion of women and other underrepresented groups in science a high priority (Williams, 2007).

\section{COLLABORATION OPPORTUNITIES TO BROADEN PARTICIPATION IN AND FROM AFRICA}

A reviewer of an earlier version of this article remarked that the challenges associated with broadening participation in Africa are fundamentally not different from those in other parts of the world. This could not have been put better and emphasizes that the rest of the world has much to learn from challenges and solutions from the African continent. Mechanisms for sharing best practices globally represent means for floating all boats a little higher. We conclude our essay by highlighting examples and facets that enhance biological science and education and broaden participation in the scientific enterprise for our students locally and globally. We propose that these bidirectional initiatives could help build capacity in African institutions or transfer expertise from Africa to elsewhere in the world.

\section{Collaborate for Education as Well as for Research}

Equitable collaborations are very often mutually beneficial. In Africa, where a large proportion of published research is from collaborative endeavors, collaboration enhances the quality as well as the overall output of African scientists. What is often underappreciated, however, is that Northern scientists who collaborate with Africans perform higher-impact research than their peers who do not (Blom et al., 2016). Most academic researchers working at universities and colleges have a joint mandate to teach and perform research, and for many of us, the boundaries between these two fundamental responsibilities are fuzzy. Research programs that are cocreated and open and intentionally build sustainable capacity have a better chance of producing long-term research and scientific outcomes (Yozwiak et al., 2016).

\section{STEM Curricular-Exchange Programs}

There are many more study-abroad programs for American students in Africa in the arts, humanities, and social sciences than in the STEM disciplines. For students who desire international opportunities, early exposure to science on a different continent could be a hook for retention. American science undergraduates often gravitate toward health-service internships in lower-income countries for which, having no clinical training, they are sometimes underprepared, primarily because of the absence of other options. Very few African internships offer American students scientific experiences. However, there are several examples of bicontinental education and research being justifiable and feasible for undergraduates. Examples in the biological sciences include but are not limited to ecology and biodiversity research, natural product biochemistry, or taxonomy. When programs exist, they are very popular and often oversubscribed.

Some of the challenges associated with establishing studyabroad programs include the high cost of travel, but for students going to Africa, this can be offset by lower fees. In countries where strikes have disrupted academic calendars (e.g., in Nigerian universities), study-abroad semesters or years may be difficult to fit into undergraduate schedules. In these situations, summer research options can actually offer many advantages, because visiting students can attend when the African school is in session and therefore partake of greater opportunities to interact with other undergraduates. Students who perform scientific research in another country benefit from many learning experiences simultaneously (e.g., see the student blog http://blogs.haverford.edu/university-of-ghana/2010 for one project involving four American students comentored by one of us, I.N.O., several years ago, all of whom subsequently pursued employment or advanced training in science). Such experiences illustrate to students that science and global connectivity are not mutually exclusive, and they also strengthen collaborative links between the students' supervisors. Although there are few extramural programs supporting this type of endeavor, many institutions recognize their value to undergraduate STEM education and will offer intramural support if presented with a compelling proposal. Investigators can apply grantbased research-training supplements or student research fellowships to fund undergraduate research-based exchanges between African countries and North America or other parts of the world. There are very few bilateral exchanges with African students seeking to pursue part-time studies or research elsewhere. International study-abroad programs are very often bilateral, but bilateral exchanges with African institutions are rare (Zeleza, 2013).

\section{Joint Training Programs Should Be Flexible}

Relatively few of Africa's institutions have doctoral programs, and fewer offer postdoctoral training because of financial and human resource constraints. African universities are in turn held back by this shortage of postgraduate training opportunities. Well-run sandwich $\mathrm{PhD}$ and postdoctoral programs between African and other countries offer better skills and build research capacity, promote bidirectional technology transfer, and enhance collaborative links in the long term. Joint programs and affirmative action programs are more accessible to underrepresented African students (such as first-generation literates and women) Encouraging students from Africa to undertake short-term training or research abroad is more useful and more practicable for students, often women, who cannot be away from their families for long periods (Cooksey et al., 2003; Elliott et al., 2015; Sewankambo et al., 2015). Examples of formal joint programs with evidence of success include the following:

- Karolinska Institute, Sweden, with Makerere University, Uganda, and Stellenbosch University, South Africa: http:// ki.se/en/education/collaboration-within-doctoral-education

- Norwegian Programme for Capacity Development in Higher Education and Research for Development (NORHED) in higher education institutions in several countries in Africa and on other continents: www.norad.no/norhed

- Cambridge-Africa Programs supported by the University of Cambridge, the Wellcome Trust, and other funders (Elliott et al., 2015): www.cambridge-africa.cam.ac.uk, including THRiVE, which has now evolved into a DELTAS program (see last entry)

- Danida's bilateral program for Enhancement of Research Capacity in several developing countries, including universities in Ghana, Uganda, Tanzania, Kenya, and Malawi 
- National Institutes of Health's Fogarty International Center: www.fic.nih.gov/Funding/NonNIH/Pages/predoctoral -graduate.aspx

- Predoctoral fellowships offered by the Swedish International Federation of Science: www.ifs.se

- Multiple African countries and the United States through Fulbright predoctoral fellowships: www.cies.org/region/ africa-sub-saharan

- Wellcome Trust-initiated-now Alliance for Accelerating Excellence in Science in Africa (AESA) - programs for Developing Excellence in Leadership, Training and Science in Africa (DELTAS) initiative projects, including Training Health Researchers into Vocational Excellence in East Africa, Developing Excellence in Leadership and Genetic Training for Malaria Elimination in Sub-Saharan Africa, African Science Partnership for Intervention Research Excellence, Consortium for Advanced Research Training in Africa, Initiative to Develop African Research Leaders, African Mental Health Research Initiative, Sub-Saharan African Consortium for Advanced Biostatistical Training, Sub-Saharan African Network for TB/HIV Research Excellence, West African Centre for Cell Biology of Infectious Pathogens, Makerere University-UVRI Centre for Excellence for Infection and Immunity Research and Training, and Malaria Research Capacity Development in West and Central Africa: http://aasciences .ac.ke/aas/en/academy/academy-pages/developing -excellence-in-leadership-training-and-science-deltas -africa-initiative

Because DELTAS are Africa-based training initiatives that have a global outlook, they offer scientists on the continent and elsewhere the opportunity to contribute broadly to training in Africa. Interested scientists should contact site leaders in programs of relevance (http://aasciences.ac.ke/ aas/en/academy/academy-pages/deltas-africa-grantees). One of the important facets of joint programs highlighted by this scheme is that many of its principal investigators were themselves beneficiaries of joint programs.

These and other programs that also build skills for intercultural dialogue that extend beyond the supported fellow to his or her host institution should be encouraged. Joint programs offered to African scientists often have coercive retention clauses, but joint programs offered to non-African students to spend time in Africa are less likely to come with these restrictions. In our experience and that of other African science leaders, providing flexible conditions achieves better results than coercive conditions (Ochola and Gitau, 2009; Murenzi, 2011). Graduates often do not emigrate if they are assured of viable research programs. A graduate could also choose to come back several years later with even more valuable postdoctoral qualifications or may engage in a diaspora initiative that could benefit the home country (Cho, 2004; Kaba, 2011; Tonegawa and Matlhagela, 2015). Programs that include multiple African institutions have the added benefit of establishing links among them, which could be vital for pooling capacities and encouraging retention (Elliott et al., 2015).

Many of these programs implement affirmative action for underrepresented groups, including women. This has been the case with the NORAD/NORHED program. The recently inaugurated Next Einstein Forum began with an overrepresentation of men among its fellows and then sent out repeated calls for women applicants. Eventually, six women and nine men were appointed to the initial fellow class, perhaps encouraging women to pursue science on the continent. When programs exclusively or almost exclusively appoint men, efforts should be made to study the applicant pool and selection program to identify mechanisms that could lead to the appointment of talented African women.

\section{"Global" Science Should Be Truly Global}

Recent commentaries in the foremost science journals have mentioned that insisting on female representation on review panels, at symposia, and in other high-profile science fora is helping to address underrepresentation of women in science. We note that "international" and "global" initiatives are spearheaded, judged, and presented with underrepresentation of Southern scientists, particularly Africans. The problem does not rest with opinion and evaluation. Even reports and other articles purporting to provide the "global" situation in geographically sensitive fields like epidemiology or environmental sciences often underrepresent or even entirely omit Africa (Okeke and Wain, 2008). When justification is offered, the reasoning is that African scientists are few and data are often hard to come by. The same could be argued for women, but insisting on representation has been an important step in addressing the imbalance, and the ASM's purposeful steps to improve gender parity among speakers at its general meeting could also be applied to world regions that are underrepresented in science. Those steps included informing the program committee of the extent of gender imbalances, sensitizing them to the fact that female conveners were more likely to select female speakers, and challenging the committee to resolve the imbalances (Casadevall, 2015).

The ASM's ability to correct the imbalance within a year demonstrates what is possible with decisive, multipronged action and will have long-term effects, because women in training are more likely to stick with science if models for their future careers are visible and the spaces in which they work value their contributions. African science students could be better positioned to think of themselves as advancing knowledge globally if they see other Africans doing this today. And while there are few successful African scientists, there are certainly some. Non-Africans, including undergraduate students, would be equally served by access to the scientific opinions and experiences that our continent has to offer if more of these opinions were in the public sphere. One other way to increase African participation in international scientific discourse is to have more of this discourse at venues proximal to African scientists: that is, on the African continent. This will also afford visiting scientists opportunities to build collaborations with Africa.

\section{ACKNOWLEDGMENTS}

I.N.O. and C.P.B. are grateful to the U.S. National Institutes of Health's Fogarty International Center for the Medical Education Partnership Initiative in Nigeria (MEPIN) award to the University of Ibadan, which is enabling curricular innovation in health and allied biomedical science programs at our university. The funder had no role in initiation, preparation, review, or approval of the article. We thank Dr. Adebayo Shittu, Professor O. Tomori, and Kwadwo Kojo Sarpong for helpful discussions. 


\section{REFERENCES}

Academy of Science of South Africa (2012). The State of Women in Science in Swaziland: Results of a Survey, Pretoria, South Africa, 58

Adichie CN (2012). We Should All Be Feminists, New York: Vintage.

African Union (2006). Second Decade of Education for Africa (2006-2015) Plan of Action, Addis Ababa, Ethiopia, 60.

Anyanwu OE (2011). The Politics of Access: University Education and Nation-Building in Nigeria, 1948-2000, Calgary, Canada: University of Calgary Press.

Awe B (2005). The lyalode in the traditional Yoruba political system. In: Readings in Gender in Africa, ed. A Cornwall, Bloomington, IN/Oxford, UK: Indiana University Press/James Currey, 196-200.

Bassioni G, Adzaho G, Niyukuri D (2016). Brain drain: entice Africa's scientists to stay. Nature $535,231$.

Blom A, Lan G, Adil M (2016). Sub-Saharan African Science, Technology, Engineering, and Mathematics Research: A Decade of Development, Washington, DC: World Bank Publications.

Bunting I, Cloete N, Van Schalkwyk F (2014). Data on Eight Flagship Universities in Africa 2009-2011. In Harvard Dataverse. https://dataverse.harvard edu/dataset.xhtml?persistentld=doi:10.7910/DVN/25427 (accessed 23 March 2017)

Casadevall A (2015). Achieving speaker gender equity at the American Society for Microbiology General Meeting. mBio 6, e01146-15.

Cho A (2004). A foot in each country. Science 304, 1286.

Chunii B (2015). TWAS and the horizons of science. TWAS Newsletter 27, 2.

Cooksey B, Levey LA, Mkude DJ (2003). Higher Education in Tanzania: A Case Study, Oxford, UK: James Currey.

Cornwall A (ed.) (2005). Readings in Gender in Africa, Bloomington, IN/ Oxford, UK: Indiana University Press/James Currey.

Crane JT (2013). Scrambling for Africa: AIDS, Expertise, and the Rise of American Global Health Science, Ithaca, NY: Cornell University Press.

Elliott A, Nerima B, Bagaya B, Kambugu A, Joloba M, Cose S, Pantaleo G, Yazdanbakhsh M, Mabey D, Dunne D, et al. (2015). Capacity for science in sub-Saharan Africa. Lancet 385, 2435-2437.

Gates SJ, Mirkin C (2012). Engage to Excel. Science 335, 1545-1545.

Geissler PW, Okwaro F (2014). Developing world: discuss inequality. Nature 513, 303.

Gregg-Jolly LA, Kington R, Lopatto D, Swartz JE (2011). Benefits of intertwining teaching and research. Science 331, 532.

Hippel Wv, Lerner JS, Gregerman SR, Nagda BA, Jonides J (1998). Undergraduate student-faculty research partnerships affect student retention. Rev High Educ 22, 55-72

Kaba AJ (2004). Africa's migration brain drain: the costs and benefits to the continent. Chimera 2(3), 19-30

Kaba AJ (2011). The status of Africa's emigration brain drain in the 21st century. West J Black Stud 35, 187-195.

Lamikanra A, Okeke IN (1997). A study of the effect of the urban/rural divide on the incidence of antibiotic resistance in Escherichia coli. Biomed Lett 55, 91-97.
Manuh T, Gariba S, Budu J (2007). Change \& Transformation in Ghana's Publicly Funded Universities: A Study of Experiences, Lessons \& Opportunities, Oxford UK/Accra New Town, Ghana: James Currey/Woeli Publishing Services.

Mário M, Fry P, Levy L, Chilundo A (2003). Higher Education in Mozambique: A Case Study, Oxford, UK: James Currey.

Martinez ED, Botos J, Dohoney KM, Geiman TM, Kolla SS, Olivera A, Qiu Y, Rayasam GV, Stavreva DA, Cohen-Fix O (2007). Falling off the academic bandwagon: women are more likely to quit at the postdoc to principal investigator transition. EMBO Rep 8, 977-981.

Mouton J (2008). Africa's science decline: the challenge of building scientific institutions. Harvard Int Rev 30, 46-51.

Moyi Okwaro F, Geissler PW (2015). In/dependent collaborations: perceptions and experiences of African scientists in transnational HIV research Med Anthropol Q 29, 492-511.

Murenzi R (2011). Give the new generation a chance. Nature 474, 543.

Niemann YF (2012). The making of a token: a case study of stereotype threat stigma, racism and tokenism in academe. In: Presumed Incompetent: The Intersections of Race and Class for Women in Academia, ed. G Gutiérrez y Muhs, Boulder: University Press of Colorado, 336-355.

Ochola LI, Gitau E (2009). Challenges in retaining research scientists beyond the doctoral level in Kenya. PLoS Negl Trop Dis 3, e345.

Okeke IN, Wain J (2008). Post-genomic challenges for collaborative research in infectious diseases. Nat Rev Microbiol 6, 858-864.

Okeke-Ihejirika PE (2004). Negotiating Power and Privilege: Igbo Career Women in Contemporary Nigeria, Athens: Center for International Studies, Ohio University.

Olabisi B (2014). Action, not words, will empower Africa's women scientists www.scidev.net/global/gender/opinion/action-not-words-will-empower -africa-s-women-scientists.html (accessed 23 March 2017).

Pearson $\mathrm{H}$ (2015). The lab that knows where your time really goes. Nature $526,492-496$

Ramsay S (2001). No closure in sight for the 10/90 health-research gap Lancet 358,1348

Sewankambo N, Tumwine JK, Tomson G, Obua C, Bwanga F, Waiswa P, Katabira E, Akuffo H, Persson K, Peterson S (2015). Enabling dynamic partnerships through joint degrees between low- and high-income countries for capacity development in global health research: experience from the Karolinska Institutet/Makerere University partnership. PLoS Med 12, e1001784.

Tonegawa S, Matlhagela K (2015). Q\&A: memory man. Nature 526, S55-S56 United Nations Educational Scientific and Cultural Organization (2015) UNESCO Science Report: Towards 2030, Paris, France.

Williams DA (2007). Achieving inclusive excellence: strategies for creating real and sustainable change in quality and diversity. About Campus 12(1) $8-14$.

Yozwiak NL, Happi CT, Grant DS, Schieffelin JS, Garry RF, Sabeti PC, Andersen KG (2016). Roots, not parachutes: research collaborations combat outbreaks. Cell 166, 5-8.

Zeleza P (2013). Engagements between African Diaspora Academics in the US and Canada and African Institutions of Higher Education: Perspectives from North America and Africa, New York: Carnegie Corporation. 